\title{
Necrotizing Myelopathy Associated with Malignancy Caused by Herpes Simplex Virus Type 2: Clinical Report of Two Cases and Literature Review
}

\author{
Masanori NaKagawa, Akinori NaKamura, Ryuji KubOTA, Tomokazu KaKAZU*, \\ Mutuo KUBA*, Keisyun NAKASONE* and Teruo IWAMASA**
}

\begin{abstract}
Two cases of necrotizing myelopathy, one with lung carcinoma and the other with adult $T$ cell leukemia (ATL), displayed flaccid paraplegia and sphincter dysfunction. Both cases did not show any direct neoplastic cell invasion of the spinal cord. Pathologically, diffuse and random necrosis was found in the spinal cord in both cases. In the case of ATL, small numbers of inclusion bodies in the nerve cell nuclei were demonstrated. Using polyclonal and also monoclonal antibodies, herpes simplex virus type 2 (HSV-2) was clearly demonstrated in the spinal cord in both cases. By electron microscopy, numerous herpes virus particles were observed in the spinal cord in both cases. The usefulness of electrophysiological studies should be emphasized in the differentiation of these cases from others which might also display flaccid paraplegia. The possibility of necrotizing myelopathy caused by HSV-2 should always be considered in the differential diagnosis of spinal cord diseases displaying flaccid paraplegia.
\end{abstract}

Key words: Paraneoplastic syndrome, Spinal cord necrosis, Electrophysiology

In cases of malignant disease, myelopathy caused by direct neoplastic cell invasion of the spinal cord may occur. Radiation therapy, chemotherapy and also an insufficiency of certain vitamins may also contribute to the myelopathy. However, Mancall and Rosales (1) reported two cases of necrotizing myelopathy which lacked such clearly defined causes. They also reported that necrotizing myelopathy might be a result of the deranged metabolic condition caused by malignancy, Ojeda (2) stressed that this rare disorder "necrotizing myelopathy associated with malignancy" might be diagnosed after the known clear causes of the spinal cord damage are excluded. Therefore, necrotizing myelopathy associated with malignancy was considered to be a paraneoplastic syndrome. Recently, we observed two cases of necrotizing myelopathy associated with malignancy which we firstly con- sidered to be included in this rare category, "paraneoplastic necrotizing myelopathy" both clinically and pathologically. Surprisingly however, herpes simplex virus type 2 (HSV-2) was clearly demonstrated immunohistochemically in the spinal cord in both cases. We report here the detailed results of clinical findings, including the electrophysiological examinations. The pathological details have already been published (3).

\section{CASE REPORTS}

Case 1. A 64-year-old man was first seen at Naha Prefectural Hospital on May 27, 1988 with the chief complaint of lumbago, and a history of dry cough since January 1988. On examination an abnormal shadow was found in the upper lobe of the right lung. On June 4, 1988, the patient displayed gait disturbance and severe lumbago. On June 10, 1988,

From Department of Neurology, *Department of Internal Medicine, National Okinawa Hospital, Ginowan and

**Department of Pathology, Ryukyu University School of Medicine, Nishihara

Received for publication January 8, 1990; Accepted for publication November 20, 1990

Reprint requests should be addressed to Masanori Nakagawa, MD, Department of Third Internal Medicine,

Kagoshima University, Kagoshima 890, Japan 
a diagnosis of adenocarcinoma of the lung was obtained by transbronchial lung biopsy. Soon there after, complete flaccid paraplegia and sphincter dysfunction became apparent. On June 18, 1988, the patient was admitted to the National Okinawa Hospital. There was no history of any other neurological disorders. His family history was noncontributory.

On the day of admission, physical examinations revealed blood pressure of $140 / 80 \mathrm{mmHg}$, heart rate $88 / \mathrm{min}$, body temperature $37.8^{\circ} \mathrm{C}$ and respiratory rate $22 / \mathrm{min}$. Moist rales were auscultated in the upper lobe of the right lung. The patient was alert and cooperative. No abnormality was noticed in the cranial nerves system and upper extremity movement was normal. The sign of meningial irritation was not observed. There was flaccid paraplegia and areflexia in both knees and ankles, and total sensory loss from L1 down. There was no Babinski sign. Sphincter dysfunction was observed. Obstructive pneumonia at the S3 area of the right lung was demonstrated on the X-ray film.

Laboratory examinations showed an ESR of 48 $\mathrm{mm} / 1 \mathrm{~h}, \mathrm{WBC} 12,400 / \mathrm{mm}^{3}$, positive CRP and a slight increase of $\gamma$-GTP, BUN and creatinine. TPHA and anti-HTLV-1 antibodies were not found in serum. Blood gas was normal. Lumbar CSF was normal except for an increased protein level (182 $\mathrm{mg} / \mathrm{dl})$.

Electrophysiologically, the peripheral nerve conduction velocity and somatosensory evoked potentials (SEP) over the median nerves were normal. Tibial nerve SEP recorded by the method of Arimura et al (4) was detected from the midline of the lumbar area posteriorly with needle electrodes just rostral to the spine of the 12th thoracic vertebra, but was not detected at the scalp corresponding to the foot somatosensory area. Electromyography revealed fibrillation potentials and positive sharp waves in the leg muscles. MRI of the spine and myelography demonstrated a normal spinal canal and cord.

Except for doxorubicin, no other chemotherapy nor radiotherapy were used to treat his lung carcinoma because of the patient's poor general condition. A single dose of only $20 \mathrm{mg}$ of doxorubicin was injected into the right pleural cavity after aspiration of pleural effusion. His neurological symptoms did not fluctuate. The patient died as a result of extension of the lung carcinoma on the 27th day after the onset of flaccid paraplegia.

Necropsy findings: Necropsy, including that of the spinal cord, was performed. However, permission for brain examination was not obtained. The cancer mass completely occupied the upper lobe of the right lung. Metastases were found in the middle and lower lobes of the right lung and also in the upper lobe of the left lung. Furthermore, in the thyroid and left adrenal gland, small foci of cancer metastasis were observed. The spinal cord was slightly softened. The dura mater and leptomeninges did not show any remarkable findings. Microscopically, poorly differentiated adrenocarcinoma was observed in the upper lobe of the lung. There was no direct neoplastic cell invasion and no vascular lesion in the spinal cord. Diffuse and random necrosis was found in both grey and white matter of the spinal cord (Figs. 1, 2). A few perivascular lymphocytic infiltrations were observed after detailed examination of the serial sections of the spinal cord. The necrosis was most prominent at level L2-L4 and extended to the C2 level, to a lesser degree. By electromicroscopy, herpes virus particles, $100-120 \mathrm{~nm}$ in diameter, were demonstrated in the nerve cells, HSV-2 antigen was clearly demonstrated immunohistochemically using polyclonal and also monoclonal anti-HSV-2 antibodies (Fig. 3). However, HSV-1 and cytomegalovirus antigens were not detected. The immunohistochemical reaction of $\mathrm{IgG}, \mathrm{IgM}, \mathrm{C} 3$ and fibrinogen did not reveal any specific findings (3).

Case 2. A 74-year-old woman was admitted with chief complaints of fever, nausea and loss of appetite on April 11, 1988. She had received treatment for pulmonary tuberculosis until Jan. 17, 1988. There were no similar cases in her family. On admission, her physical examination showed a blood pressure of $110 / 50 \mathrm{mmHg}$, heart rate $94 / \mathrm{min}$ and body temperature $38.9^{\circ} \mathrm{C}$. There were no other abnormal physical findings. The results of neurological examination were normal. Laboratory examinations showed an ESR of $22 \mathrm{~mm} / 1 \mathrm{~h}, \mathrm{WBC} 12,300 / \mathrm{mm}^{3}$, and positive CRP. Serum $\gamma$-GTP and lysozyme levels were slightly increased. The serum LDH level was also increased, showing 1,349 IU/1 (normal: $120-520$ ), $48 \%$ of which was LDH2. Anti-HTLV-1 


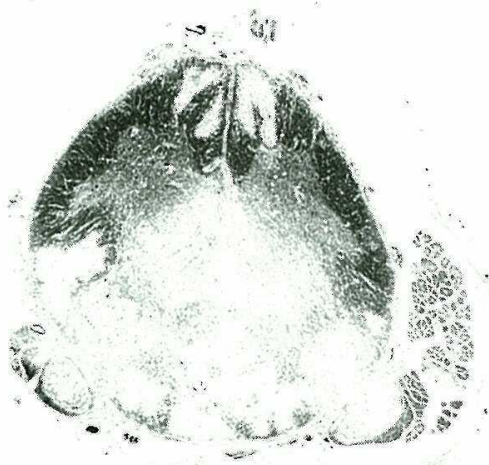

Fig. 1. Transverse section of the spinal cord of case 1 at the level of L2 showing extensive necrosis of white and gray matter. Kluver-Barrera stain.

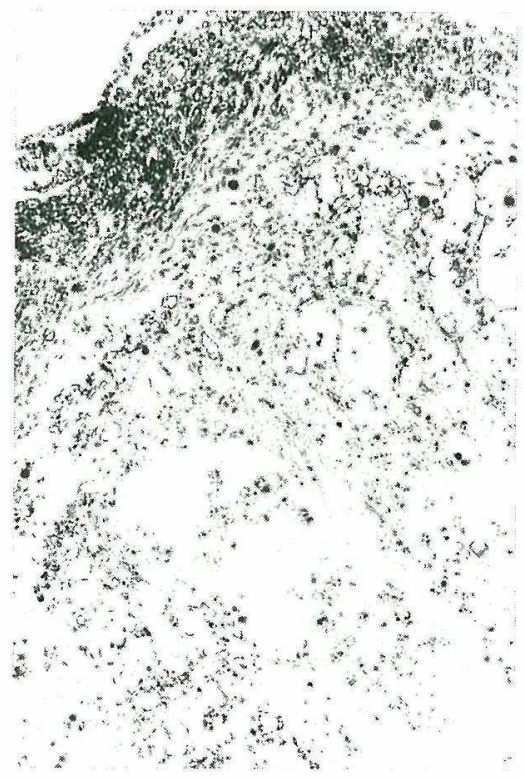

Fig. 2. Necrosis and swelling of myelin with reactive gliosis at the level of L3 (case 1). KluverBarrera stain $\times 130$.

antibody was positive, showing $4,096 \times$ in serum by particle agglutination (PA) method. Bone marrow aspiration cytology was normal except for an increase in atypical lymphocytes $(8 \%)$. The tumor makers, $\beta 2$ microglobulin and ferritin, were moderately increased. Examination of T lymphocyte

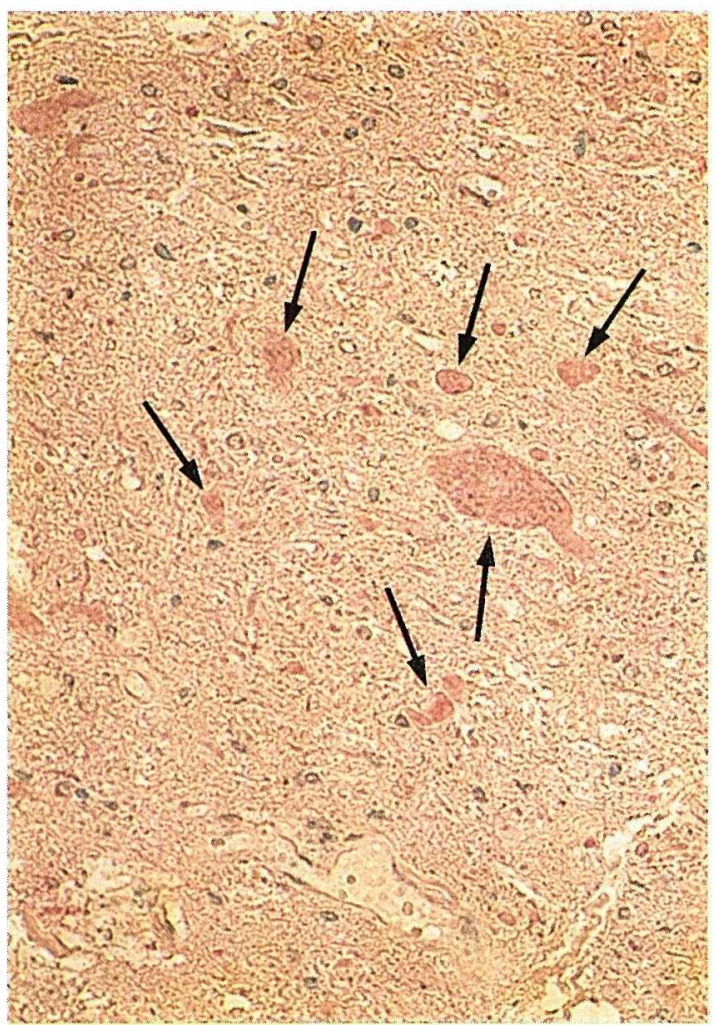

Fig. 3. Immunohistochemical staining of HSV-2 antigen by use of polyclonal antibody in the necrotic lesion (case 1). Arrows indicate necrotic cells. $\times 180$.

subsets in peripheral blood demonstrated an increased ratio of CD3, CD4, CD8, OKIa1 and CD25 positive cells to total lymphocytes, suggesting an activated state of T lymphocytes. CSF was normal.

The patient had a persistent fever of over $38^{\circ} \mathrm{C}$. The X-ray film indicated diffuse pneumonia in both lungs. However, anti-Koch's agents and antibiotics failed to improve her condition. On June 3, 1988, her level of consciousness was slightly deteriorated but she quickly recovered. At the same time, enlargement of the axillary and inguinal lymph nodes was noticed. ${ }^{67} \mathrm{Ga}$ scintigraphy showed multiple abnormal deposits in neck, upper mediastinum, lung and abdomen. Five percent of lymphocytes in peripheral blood and bone marrow showed cribriform nuclei, typical of adult T cell leukemia (ATL); a diagnosis of ATL was made. On June 13, 1988, the chest X-ray indicated pleural effusion in the right lung. Smears of the aspiration fluids contained 
numerous abnormal lymphocytes and mononuclear cells. On June 27,1988 , a small nodular lesion $(1 \times 1$ $\mathrm{cm}$ ) was noticed in the right temporal region, indicating an accumulation of abnormal lymphocytes. On the same day, papular skin eruptions appeared on the patient's trunk, and she complained of lumbago and numbness from L1 down. On July 4, 1988 , flaccid paraplegia in the legs, and neck stiffness, with a mild disturbance of consciousness were observed. There was an absence of knee and ankle tendon reflexes, and there was no Babinski sign. However, neurological examination of cranial nerves and brain $\mathrm{CT}$ did not show any remarkable abnormalities. At the time, the CSF was clear with white blood cells numbering $5 / \mu 1$ (100\% mononuclear cells) and a total protein concentration of $120 \mathrm{mg} / \mathrm{dl}$. Tests for anti-HTLV-1 antibody were positive, with a titer of $124 \times$ in the CSF by PA method. Some abnormal mononuclear cells were observed in the CSF. Meningial invasion of ATL cells was suspected, and $10 \mathrm{mg}$ of methotrexate and $30 \mathrm{mg}$ of hydrocortisone were injected intrathecally. The axillary and inguinal lymph nodes were swollen. Oral candidiasis was observed. On July 6, 1988, hypercalcemia $(12 \mathrm{mg} / \mathrm{dl}$, normal value: $8.7-10.4)$ and cytopenia showing $\mathrm{RBC}$ of $241 \times 10^{4} / \mathrm{mm}^{3}$, WBC of $700 / \mathrm{mm}^{3}$ and platelet of $64,000 / \mathrm{mm}^{3}$ were observed. The patient died of respiratory insufficiency caused by pneumonia on July 8, 1988. The patient did not receive any radiotherapy or chemotherapy except for the intrathecal injections.

Necropsy findings: Necropsy was performed $6 \mathrm{~h}$ after the patient's death. Permission for brain examination was not obtained. Both lungs were congested and edematous with scattered foci of hemorrhages. In the upper lobe of the right lung, a fibrous tuberculous scar was found. The bone marrow of the sternum, vertebrae and iliac bones was hypoplastic. There were multiple ulcers in the large intestine. The lymph nodes of the mediastinum and the large intestines were swollen. The liver showed slight fatty degeneration. The spinal cord was slightly softened but showed no abnormality throughout its whole length. The leptomeninx was normal. Microscopically, the bone marrow was hypoplastic and a small number of lymphocytic leukemia cells with cribriform nuclei (ATL cells) were present. In addition, there were large mononuclear cells with wide eosinophilic cytoplasms and large nuclei, some of which had large nuclear inclusions (Cowdry type A inclusion bodies). The invasion of ATL cells was also found in the lymph nodes of the mediastinum and the large intestine. Horizontal sections of the spinal cord revealed foci of massive necrosis and occasional slight hemorrhage. The necrosis was found in all segments, but was most prominent at the lumbar level. There was no leukemic cell infiltration in the spinal cord, leptomeninx, posterior root fibers or dorsal ganglia. The intraspinal vessels were not disrupted. The blood vessels showed no abnormality. Fibrin thrombi were not detected even after examination of serial sections. Some perivascular lymphocyte infiltration in the spinal cord, and slight lymphocytic infiltration in the leptomeninx were observed. Immunohistochemically, numerous HSV-2 antigens were stained with polyclonal and also monoclonal antibodies in all segments of the spinal cord. In the bone marrow, the large mononuclear cells (mentioned above) were also stained positively. The atypical large cells observed in the CSF were considered to be these large mononuclear cells. Other immunohistochemical reactions, such as for HSV-1 and cytomegalovirus did not reveal any remarkable findings. Electron microscopic investigation of the spinal cord showed large numbers of herpes virus particles, measuring 100-120 nm in diameter (3).

\section{DISCUSSION}

The initial symptoms of necrotizing myelopathy associated with malignancy (PNM: paraneoplastic necrotizing myelopathy) are muscle weakness and sensory disturbance of the legs, progressing to flaccid paraplegia with total sensory loss and sphincter dysfunction within a few days $(1,2)$. In the majority of reported cases, the patient dies shortly after the appearance of neurological symptoms. Histopathologic findings are characteristic showing diffuse and random necrosis in spinal cord with slight perivascular lymphocytic infiltration $(1,2,5-7)$. Both cases in this report showed such clinical and pathological features. Clinically, in the differential diagnosis, the possibility of such disease as polyradiculoneuropathy (8) which may also display flaccid paraplegia of legs must be eliminated. Electrophysiological study, 
particularly of the tibial nerve SEP is beneficial in the diagnosis of PNM. To date, there is no paper concerning the electrophysiological findings in PNM in the literature.

In 1984, Ojeda (2) reported two original cases and reviewed 22 other cases of PNM which had been reported since 1903. Here, we reviewed 4 additional reports $(9-12)$; together with the present two cases, a total of 30 cases were reviewed as listed in Table 1. The average age of the 30 cases (18 males and 12 females) is 51.2 , and the median survival period after the onset of paraplegia is 41.6 days. Malignancy associated with PNM included the following: lung carcinoma (8 cases), malignant lymphoma (7 cases), leukemia (4 cases), breast carcinoma ( 3 cases), prostatic carcinoma ( 2 cases) and others. Histopathologically, none of these cases showed viral inclusion in the spinal cord and were not examined immunohistochemically for viral infection. In the present two cases, HSV-2 infection in the spinal cord was clearly demonstrated. They were different from typical HSV infection, such as

Table 1. Necrotizing Myelopathy Associated with Malignancy: Literature Review

\begin{tabular}{|c|c|c|c|c|c|c|}
\hline $\begin{array}{c}\text { Case } \\
\text { No }\end{array}$ & \multicolumn{2}{|c|}{ Author/yr } & \multirow{2}{*}{$\begin{array}{l}\text { Age/sex } \\
57 / M\end{array}$} & \multirow{2}{*}{$\begin{array}{l}\text { Malignancy } \\
\text { Prostatic } \mathrm{Ca}\end{array}$} & \multirow{2}{*}{$\begin{array}{l}\begin{array}{l}\text { Survival after } \\
\text { paraplegia (day) }\end{array} \\
35\end{array}$} & \multirow{2}{*}{$\begin{array}{l}\begin{array}{l}\text { Spinal } \\
\text { cord } \\
\text { lesions }\end{array} \\
\mathrm{T} 8-\mathrm{T} 11\end{array}$} \\
\hline 1 & Nonne $^{a}$ & 1903 & & & & \\
\hline 2 & Nonne $^{a}$ & 1919 & $65 / \mathrm{M}$ & Lung $\mathrm{Ca}$ & 60 & T1-L5 \\
\hline 3 & Feidel $^{\mathrm{a}}$ & 1921 & $23 / \mathrm{M}$ & Leg sarcoma & 18 & C4-L5 \\
\hline 4 & D'Antona $^{\mathrm{a}}$ & 1926 & $41 / \mathrm{M}$ & Lung $\mathrm{Ca}$ & 18 & $\mathrm{~T} 2-\mathrm{S} 5$ \\
\hline 5 & Moersh $^{\mathrm{a}}$ & 1934 & $17 / \mathrm{F}$ & Skin $\mathrm{Ca}$ & 14 & Whole \\
\hline 6 & $\mathrm{Juba}^{\mathrm{a}}$ & 1938 & $47 / \mathrm{M}$ & Gastric $\mathrm{Ca}$ & 60 & $\mathrm{~T}-\mathrm{L}$ \\
\hline 7 & Lhermitte $^{\mathrm{a}}$ & 1941 & $65 / \mathrm{M}$ & Lung $\mathrm{Ca}$ & 21 & $\mathrm{~L} 1-\mathrm{S} 3$ \\
\hline 8 & Jaffe (19) & 1943 & $70 / \mathrm{F}$ & Thyroid Ca & 31 & $\mathrm{~T}-\mathrm{L} 1$ \\
\hline 9 & Williams (20) & 1962 & $32 / \mathrm{M}$ & Ma Lymphoma & 15 & $\mathrm{C} 6-\mathrm{L} 2$ \\
\hline 10 & Mathieson $^{\mathrm{a}}$ & 1963 & $74 / \mathrm{F}$ & Breast $\mathrm{Ca}$ & 60 & $\mathrm{C} 3-\mathrm{S} 3$ \\
\hline 11 & Mancall (1) & 1964 & $55 / \mathrm{F}$ & Lung Ca & 34 & $\mathrm{C} 1-\mathrm{L} 2$ \\
\hline 12 & & & $49 / \mathrm{M}$ & Lung $\mathrm{Ca}$ & 5 & $\mathrm{~T} 4-\mathrm{T} 6$ \\
\hline 13 & Richter (21) & 1968 & $43 / \mathrm{M}$ & Ma Lymphoma & 90 & $\mathrm{C} 2-\mathrm{T} 6$ \\
\hline 14 & & & $61 / \mathrm{M}$ & Ma Lymphoma & 30 & $\mathrm{~T}-\mathrm{L}$ \\
\hline 15 & Nishida (22) & 1973 & $45 / \mathrm{M}$ & Ma Lymphoma & 30 & $\mathrm{C} 2-\mathrm{C} 6$ \\
\hline 16 & $\mathrm{MGH}^{\mathrm{b}}(23)$ & 1976 & $64 / F$ & Ovarian $\mathrm{Ca}$ & 50 & $\mathrm{C} 8-\mathrm{T} 12$ \\
\hline 17 & Reznik (24) & 1979 & $16 / \mathrm{F}$ & Leukemia & 10 & Whole \\
\hline 18 & Whiteley (25) & 1979 & $60 / \mathrm{F}$ & Ma Lymphoma & 35 & $\mathrm{C} 1-\mathrm{T} 8$ \\
\hline 19 & & & $69 / \mathrm{F}$ & Ma Lymphoma & 150 & $\mathrm{C} 1-\mathrm{S} 4$ \\
\hline 20 & & & $77 / \mathrm{M}$ & Prostatic $\mathrm{Ca}$ & 60 & $\mathrm{~T} 2-\mathrm{T} 4$ \\
\hline 21 & Lester (9) & 1979 & $66 / \mathrm{M}$ & Ma Lymphoma & 17 & $\mathrm{C} 8-\mathrm{T} 7$ \\
\hline 22 & Grisold (26) & 1980 & $16 / \mathrm{M}$ & Leukemia & 150 & $\mathrm{~T} 8-\mathrm{T} 10$ \\
\hline 23 & Sieben (27) & 1981 & $56 / \mathrm{F}$ & Breast $\mathrm{Ca}$ & 19 & $\mathrm{C}-\mathrm{T}$ \\
\hline 24 & Wilson (11) & 1983 & $79 / \mathrm{M}$ & Renal cell $\mathrm{Ca}$ & 21 & $\mathrm{~T} 4-\mathrm{S} 1$ \\
\hline 25 & Renkawek (10) & 1983 & $44 / M$ & Lung $\mathrm{Ca}$ & 21 & $\mathrm{~T} 5-\mathrm{T} 8$ \\
\hline 26 & Ojeda (2) & 1984 & $33 / F$ & Breast $\mathrm{Ca}$ & 11 & $\mathrm{C} 2-\mathrm{L} 5$ \\
\hline 27 & & & $59 / \mathrm{F}$ & Lung Ca & 30 & $\mathrm{C} 6-\mathrm{L} 2$ \\
\hline 28 & Gieron (12) & 1987 & $16 / \mathrm{M}$ & Leukemia & 120 & $\mathrm{C}-\mathrm{L}$ \\
\hline \multicolumn{7}{|c|}{ This report } \\
\hline 29 & Case 1 & & $64 / M$ & Lung $\mathrm{Ca}$ & 27 & $\mathrm{C} 2-\mathrm{S} 5$ \\
\hline 30 & Case 2 & & $74 / F$ & ATL & 5 & $\mathrm{C} 1-\mathrm{L} 5$ \\
\hline
\end{tabular}

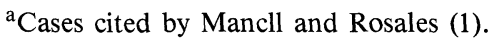

${ }^{\mathrm{b}}$ Case records of the Massachusetts General Hospital

M, male; F, female; Ca, carcinoma; Ma, malignant; C, cervical; $\mathrm{T}$, thoracic; L, lumbar; S, sacral 
Table 2. Necrotizing Myelopathy/Myelitis Caused by Herpes Simplex Virus: Literature Review

\begin{tabular}{|c|c|c|c|c|c|c|c|}
\hline Author/yr & & Age/sex & $\begin{array}{l}\text { Associated } \\
\text { conditions }\end{array}$ & $\begin{array}{l}\text { Survival } \\
\text { after } \\
\text { paraplegia }\end{array}$ & $\begin{array}{l}\text { Spinal } \\
\text { cord } \\
\text { lesions }\end{array}$ & $\begin{array}{l}\text { CSF } \\
\text { cells } \\
/ \mu 1\end{array}$ & $\begin{array}{l}\mathrm{HSV} \\
\text { type }\end{array}$ \\
\hline Klastersky (13) & 1972 & $45 / \mathrm{F}$ & None & 5 days & whole & $13,400(\mathrm{Pc})$ & I \\
\hline Koskiniemi (14) & 1982 & $21 / \mathrm{F}$ & Pregnancy & recovery & & 2 & I \\
\hline Britton (15) & 1985 & $25 / \mathrm{M}$ & AIDS & 33 days & $\mathrm{T} 7-\mathrm{T} 8$ & 0 & II \\
\hline Wiley (16) & 1987 & $57 / M$ & DM & 26 days & whole & $7,900(\mathrm{Pc})$ & II \\
\hline Ahmed (17) & 1988 & $29 / \mathrm{F}$ & None & recovery & & $210(\mathrm{Mc})$ & II \\
\hline \multicolumn{8}{|l|}{ This report } \\
\hline Case 1 & & $64 / M$ & Lung $\mathrm{Ca}$ & 27 days & $\mathrm{C} 2-\mathrm{S} 5$ & $5(\mathrm{Mc})$ & II \\
\hline Case 2 & & $74 / \mathrm{F}$ & ATL & 5 days & C1-L5 & $5(\mathrm{Mc})$ & II \\
\hline
\end{tabular}

DM, diabetes mellitus; ATL, adult T cell leukemia; Pc, Polynuclear cells; Mc, Mononuclear cells; M, male; F, female; Ca, carcinoma; C, cervical; T, thoracic; L, lumbar; S, sacral

\section{HSV encephalitis.}

On the other hand, differing from PNM, a few cases of necrotizing myelopathy caused by HSV infection have also been reported (13-17). However, these cases were not associated with malignancy and two were cured. Moreover, differing from the present cases, CSF from three patients showed an increase in the white blood cell count (Table 2). The case reported by Wiley et al (16) was associated with diabetes mellitus and showed severe perivascular lymphocytic infiltration in the spinal cord. The histological and clinical differences between PNM, including the present two cases, and other HSV infected myelopathy might depend upon the host reaction, which in turn may be related to the associated diseases. Furthermore, the HSV-2 which was isolated at the Department of Pathology, Ryukyu University School of Medicine, showed a slight difference in the DNA $\mathrm{p}$ fragment when digested by Bam HI (unpublished data). It has been reported that the DNA region, composed of $p, u$, $\mathrm{v}$ and $\mathrm{g}$ fragments, is related to high neurovirulence (18).

In cases of malignant disease showing flaccid paraplegia without direct neoplastic cell invasion into the spinal cord, the possibility of PNM caused by HSV-2 should be considered. It is necessary to study such cases virologically and immunohistochemically.

This work was supported in part by Grant 63-4 from the National Center of Neurology and Psychiatry of the Ministry of Health and Welfare, Japan.

\section{REFERENCES}

1) Mancall EL, Rosales RK. Necrotizing myelopathy associated with visceral carcinoma. Brain 87: 639, 1964.

2) Ojeda VJ. Necrotizing myelopathy associated with malignancy. Cancer 53: 1115, 1984.

3) Iwamasa $T$, Utsumi $Y$, Sakuda $H$, et al. Two cases of necrotizing myelopathy associated with malignancy caused by herpes simplex virus type 2 . Acta Neuropathol 78: $252,1989$.

4) Arimura K, Rosales R, Osame M, Igata A. Clinical electrophysiologic studies of HTLV-I-associated myelopathy. Arch Neurol 44: 609, 1987.

5) Brain L, Adams RD. A guide to the classification and investigation of neurological disorders associated with neoplasms. in: The Remote Effects of Cancer on the Nervous System, Brain L, Norris FH Jr, Eds. Grune and Stratton, New York, London, 1965, p.216.

6) Follis AGH, Netsky MG. Progressive necrotic myelopathy. in: Handbook of Clinical Neurology, vol 9, Vinken PJ, Bruyn GW, Eds. North Holland, Amsterdam-Oxford, 1970, p.452.

7) Norris FH Jr. Remote effects of cancer on the spinal cord. in: Handbook of Clinical Neurology, vol.38, Vinken PJ, Bruyn GW, Eds. North Holland, Amsterdam-Oxford, 1979, p.669.

8) Arnason BGW. Inflammatory polyradiculoneuropathies. in: Peripheral Neuropathy, Dyck PJ, Thomas PK, Lambert EL, Eds. WB Saunders, Philadelphia, 1975, p.1110.

9) Lester EP, Feld E, Kinzie JJ, Wollmann R. Necrotizing myelopathy complicating Hodgkin's disease. Arch Neurol 36: 583, 1979.

10) Renkawek K, Kida E. Combined acute necrotic myelopathy (ANM) and cerebellar degeneration associated with malignant disease. Clin. Neuropathol. 2: $90,1983$.

11) Wilson JWL, Morales A, Sharp D. Necrotizing 
myelopathy associated with renal cell carcinoma. Urology 11: 390, 1983.

12) Gieron MA, Margraf LR, Korthals JK, Gonzalvo AA, Murtagh RF, Hvizdala EV. Progressive necrotizing myelopathy associated with leukemia: Clinical, pathologic, and MRI correlation. J Child Neurol 2: 44, 1987.

13) Klastersky J, Cappel R, Snoeck JM, Flament J, Thiry L. Ascending myelitis in association with herpes-simplex virus. N Engl J Med 287: 182, 1972.

14) Koskiniemi M-L, Vaheri A, Manninen V, Nikki P. Ascending myelitis with high antibody titer to herpes simplex virus in the cerebrospinal fluid. J Neurol 227: 187, 1982.

15) Britton CB, Mesa-Tejada R, Fenoglio CM, Hays AP, Garvey GG, Miller JR. A new complication of AIDS: Thoracic myelitis caused by herpes simplex virus. Neurology 35: 1071, 1985.

16) Wiley CA, VanPatten PD, Carpenter PM, Powell HC, Thal LJ. Acute ascending necrotizing myelopathy caused by herpes simplex virus type 2 . Neurology 37: $1791,1987$.

17) Ahmed I. Survival after herpes simplex type II myelitis. Neurology 38: 1500, 1988.

18) Taha MY, Clements GB, Brown SM. The herpes simplex virus type 2 (HG52) variant $\mathrm{JH} 2604$ has a 1488 bp deletion which eliminates neurovirulence in mice. $\mathbf{J}$ Gen Virol 70: 3073, 1989.

19) Jaffe D, Freeman W. Spinal necrosis and softening of obscure origen: Necrotic myelitis versus myelomalacia. Review of literature and clinicopathologic case studies. Arch Neurol Psychiatr 49: 683, 1943.

20) Williams RA, Billings JJ, De Gruchy GC. Acute myelitis complicating lymphosarcoma. Med J Aust 1: $128,1962$.

21) Richter RB, Moore RY. Non-invasive central nervous system disease associated with lymphoid tumors. Johns Hopkins Med J 122: 271, 1968.

22) Nishida $T$, Ziegler DK. Acute necrotic myelopathy in association with lymphoma cells of the reticuloendothelial system, acute torticollis, and recurrent cardiac arrest. Confin Neurol 35: 346, 1973.

23) Case Records of the Massachusetts General Hospital. Case 26-1976. N Engl J Med 294: 1447, 1976.

24) Reznik M. Acute ascending poliomyelomalacia after treatment of acute lymphocytic leukemia. Acta Neuropathol (Berl) 45: 153, 1979.

25) Whiteley AM, Hauw JJ, Escourolle R. A pathological survey of 41 cases of acute intrinsic spinal cord disease. J Neurol Sci 42: 229, 1979.

26) Grisold W, Lutz D, Wolf D. Necrotising myelopathy associated with acute lymphoblastic leukemia. Acta Neuropathol (Berl) 49: 231, 1980.

27) Sieben GM, De Reuck JL, Debryne JC, Eecken HMV. Subacute necrotic myelopathy: Its appearance eight years after cure of a breast carcinoma. Arch Neurol 38: $775,1981$. 